\title{
Optimized cultivation of Ettlia sp. YC001 in eutrophic pond water for nutrient removal and biomass production
}

\author{
Hyung-Seok Oh, Chi-Yong Ahn, Ankita Srivastava and Hee-Mock Oh* \\ Cell Factory Research Center, Korea Research Institute of Bioscience and Biotechnology, Daejeon 34141, Korea
}

Ettlia sp. YC001, a highly settleable and productive microalga, was shown to be effective in removing nutrients and capturing suspended solids from eutrophic pond water. The optimum conditions for the Ettlia sp. YC001 cultivation were investigated using water from a landscape pond. The pond water was supplemented with different $\mathrm{N}: \mathrm{P}$ ratios by weight, and the biomass production and nutrient removal compared in batch cultures. The maximum removal rate of $\mathrm{N}$ and $\mathrm{P}$ was with an $\mathrm{N}: \mathrm{P}$ ratio of $16: 1$. Plus, the turbidity dropped to near zero within 4 days. Meanwhile, chemostat cultivation showed that the biomass productivity and nutrient removal rate increased when increasing the dilution rate, where a dilution rate of $0.9 \mathrm{~d}^{-1}$ showed the highest $\mathrm{N}$ and $\mathrm{P}$ removal rate at $32.4 \mathrm{mg} \mathrm{L}^{-1} \mathrm{~d}^{-1}$ and $1.83 \mathrm{mg} \mathrm{L}^{-1} \mathrm{~d}^{-1}$, respectively, and highest biomass and lipid productivity at $0.432 \mathrm{~g} \mathrm{~L}^{-1} \mathrm{~d}^{-1}$ and $67.8 \mathrm{mg} \mathrm{L}^{-1} \mathrm{~d}^{-1}$, respectively. The turbidity was also reduced by $98 \%$ in the chemostat cultivation. Moreover, auto-flocculation and $\mathrm{pH}$ were closely connected to the turbidity removal. As a result, this study identified the optimal N : P ratio for small pond water treatment using an Ettlia sp. YC001, while also establishing the optimal conditions for nutrient removal, turbidity reduction, and biomass production.

Key Words: biomass; Ettlia; landscape pond; nutrient removal; water treatment

\section{INTRODUCTION}

Landscape ponds are becoming increasingly abundant and popular for recreational activities in places such as parks, schools, and residential backyards. Water clarity of ponds, without algal blooms, is an important criterion for aesthetic purpose. Water transparency mainly declines due to suspended solids and excessive nutrients that can lead to eutrophication and subsequent algal blooms (Heisler et al. 2008). Yet, continuous water replacement to prevent this problem is costly, while flocculation using chemical cohesive agents and filtration to promptly reduce the tubidity level (Zhang and Wang 2000) also entails high costs and is often accompanied by secondary damage to aquatic ecosystems due to chemi- cal contamination. Moreover, conventional wastewater treatments are complex and require qualified personnel for effective management. Therefore, low-cost and sustainable water treatment strategies are still needed.

Microalgae are an important option for bioenergy production, thereby replacing fossil fuels, while also treating wastewater (Acién et al. 2016). Microalgal mitigation of nutrients originating from municipal wastewaters, surface waters, and livestock wastewaters had shown great applicability (Hammed et al. 2016). Rezvani et al. (2017) reported that Ettlia sp. grew well with nitrate-contaminated groundwater. Generally, in the wastewater treatment using microalgae, nitrogen $(\mathrm{N})$ and phosphorus $(\mathrm{P})$
(9) $\$$ This is an Open Access article distributed under the terms of the Creative Commons Attribution Non-Commercial License (http://creativecommons.org/licenses/by-nc/3.0/) which permits unrestricted non-commercial use, distribution, and reproduction in any medium, provided the original work is properly cited.
Received August 14, 2018, Accepted December 9, 2018

*Corresponding Author

E-mail: heemock@kribb.re.kr

Tel: +82-42-860-4321, Fax: +82-42-860-4594 
are main concerned nutrients to be reduced in the aspect of preventing eutrophication. However, the large-scale application of wastewater treatment systems using microalgae is difficult as they are less efficient than smallscale wastewater treatment systems and require a much wider land area. Thus, small-scale landscape ponds may be a more suitable application of microalgae wastewater treatment.

In the advanced treatment of swine wastewater by Scenedesmus quadricauda, it seemed that the growth of S. quadricauda was affected not only by $\mathrm{N}$ : P ratio of the medium but also by the absolute concentration of $\mathrm{N}$ and $\mathrm{P}$ in the medium (Park et al. 1998). The optimal cellular $\mathrm{N}$ : P ratio may be species-specific and is well known to determine the competition and dominance among microalgae (Rhee 1978, Rhee and Gotham 1980). On the other hand, Woertz et al. (2009) reported that the cellular $\mathrm{N}$ : P ratio was found to be proportional to the $\mathrm{N}$ : P ratio in wastewater. Based on these previous reports, complete removal of both $\mathrm{N}$ and $\mathrm{P}$ from wastewater was reported (Solovchenko et al. 2016, Whitton et al. 2016). Therefore, composition of algal species seems to be important for meeting the desired $\mathrm{N}$ : P ratio in wastewater. In other words, in order to keep the target microalgal strain as the dominant species, the $\mathrm{N}$ : $\mathrm{P}$ ratio of the wastewater should be adjusted according to that of the target strain by adding some amount of $\mathrm{N}$ or $\mathrm{P}$ to the wastewater.

As water clarity is an important evaluation criterion for the usage of landscape ponds, various studies have used microalgae for reducing the turbidity of wastewater. Kim et al. (2010) showed that the cyanobacterium Phormidium parchydematicum and unicellular microalga Chlorella vulgaris can be used for clay removal in turbid water by sedimentation through microalgae-clay flocculation. Chun et al. (2018) reported that the sedimentation of the inoculated Ettlia sp. YC001 in freshwater recirculating aquaculture system was not disturbed and the turbidity was under 0.1 nephelometric turbidity unit (NTU) in the treatment, a comparable grade to the control. These results indicated the possibility of using microalgae for the improvement of water clarity.

Choosing the appropriate algal strain is generally considered a key factor for successful biological wastewater treatment and biodiesel production (Scott et al. 2010). Ettlia sp. YC001 demonstrates a high settleability, eliminating the need for energy-intensive harvesting, plus it has a high biomass productivity and accumulates relatively high levels of neutral lipids and carotenoids, making it a suitable candidate for industrial applications (Yoo et al. 2013, Lee et al. 2018).
Accordingly, this study investigates the culture optimization of settable Ettlia sp. YC001 for remediation of eutrophic pond water. In addition to batch experiments, continuous cultures (chemostat) are also used to investigate the effect of biomass production and nutrient removal in the case of a continuous process. Therefore, this study examines the conditions for culturing Ettlia sp. YC001 in pond water at a smaller scale, while also examining the effective conditions for nutrient removal, turbidity reduction, and biomass production in the case of continuous cultivation.

\section{MATERIALS AND METHODS}

\section{Experimental strain and pre-cultivation}

The microalgal strain Ettlia sp. YC001 (KCTC 12109BP) was obtained from the Korean Collection for Type Cultures (KCTC) at the Korea Research Institute of Bioscience and Biotechnology (KRIBB). The Ettlia sp. YC001 was pre-cultivated in a 4-L photobioreactor (PBR) containing 3 L of a BG-11 medium (Stanier et al. 1971), plus a fresh medium was continuously supplied at a dilution rate of $0.125 \mathrm{~d}^{-1}$. A three-wavelength fluorescent lamp with peaks at 436, 546, and $611 \mathrm{~nm}$ (Cool daylight, Dulux L, 36W; OSRAM, Munich, Germany) of $240 \mu \mathrm{mol} \mathrm{m}^{-2} \mathrm{~s}^{-1}$ as determined by quantum meter (LI-250A; LI-COR Inc., Lincoln, NE, USA) was used to illuminate the culture continuously. The temperature was maintained at $25 \pm$ $1^{\circ} \mathrm{C}$ using a water circulator (JSRC-13C; JS Research Inc., Gongju, Korea), and $\mathrm{CO}_{2}$-air mixture with $1 \%(\mathrm{v} / \mathrm{v})$ of $\mathrm{CO}_{2}$ was continuously supplied.

\section{Determination of biomass and lipid production}

The cell biomass was assessed using the dry cell weight (DCW). After manual mixing, $5 \mathrm{~mL}$ of the culture solution was collected at each sampling point. The samples were then filtered using a GF/C glass-fiber filter (47 mm diameter; Whatman, Clifton, NJ, USA). After drying overnight at $105^{\circ} \mathrm{C}$, the filters were used for DCW measurements in duplicate. All the following measurements were done in duplicate and expressed as mean \pm standard deviation (SD). The total lipid content was estimated using a modified version (La et al. 2016) of the Bligh and Dyer method (1959). Finally, the lipid productivity of each cultivation system was estimated by multiplying the biomass productivity ( $\left.\mathrm{g} \mathrm{L}^{-1} \mathrm{~d}^{-1}\right)$ and total lipid content (\%) at 11th day when chemostat culture reached steady-state. The lipid 


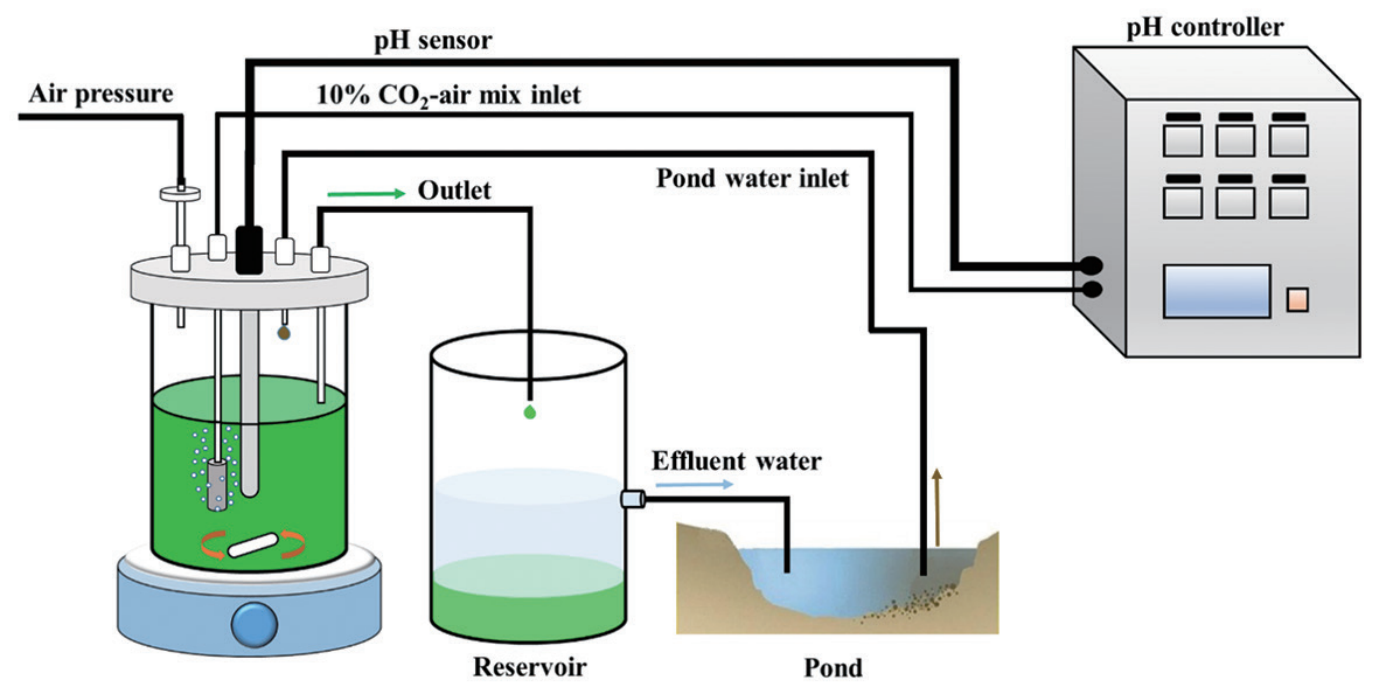

Fig. 1. Experimental design for biomass production and water clarification of small pond using Ettlia sp. YC001. The chemostat reactors included gas and culture medium in-out ports in 1-L glass wide-mouth bottles. The reservoir was set to settle down the cultured Ettlia sp. YC001 resulting in the clear residual water.

productivity was calculated using the following equation.

$$
\text { Lipid productivity }\left(\mathrm{mg} \mathrm{L}^{-1} \mathrm{~d}^{-1}\right)=
$$

Biomass productivity $\left(\mathrm{g} \mathrm{L}^{-1} \mathrm{~d}^{-1}\right) \times \frac{\text { Lipid content }(\%)}{100} \times 1,000$

\section{Optimization of $\mathrm{N}: \mathrm{P}$ ratio for Ettlia sp. YC001 cultivation in batch culture}

Four different weight ratios ( $\mathrm{g}: \mathrm{g}$ ) of total $\mathrm{N}$ and $\mathrm{P}$ in the pond water $(\mathrm{N}: \mathrm{P}=1: 1,4: 1,8: 1$, and $16: 1)$ were compared for optimal algal growth. The water was collected from a landscape pond ( $\left.36^{\circ} 22^{\prime} 05^{\prime \prime} \mathrm{N}, 127^{\circ} 21^{\prime} 47^{\prime \prime} \mathrm{E}\right)$ at the Korea Advanced Institute of Science and Technology (KAIST), Daejeon, Korea and used as the experimental medium for the growth of target strain. However, the total $\mathrm{N}$ and $\mathrm{P}$ concentrations in the pond water were 1.34 and $0.003 \mathrm{mg} \mathrm{L}^{-1}$, respectively, which are too low for the cultivation of Ettlia sp. YC001. Therefore, higher nutrient concentrations were created by the addition of nitrate and phosphate. The final concentration of $\mathrm{P}$ was fixed at $9.1 \mathrm{mg} \mathrm{L}^{-1}$, while four different $\mathrm{N}$ concentrations (10.4, 39.6, 79.0, and $151 \mathrm{mg} \mathrm{L}^{-1}$ ) were set for different $\mathrm{N}$ : P ratios. The cultivations were performed in 1-L glass widemouth bottles (GLS80; Duran Group GmbH, Mainz, Germany) containing $800 \mathrm{~mL}$ of cell-mixed pond water under continuous illumination by light $(1,050 \pm 50 \mu \mathrm{mol}$ $\left.\mathrm{m}^{-2} \mathrm{~s}^{-1}\right)$ and at a temperature range of $25 \pm 1^{\circ} \mathrm{C}$. The reactor was cylindrical with an inner diameter of $9 \mathrm{~cm}$ and a height of $22 \mathrm{~cm}$. The cultures were stirred at $200 \mathrm{rpm}$ using a stirrer (MSH-20D; Daihan Scientific Co., Ltd., Seoul, Korea). To measure the turbidity due to suspended solids except cells, the cultures were allowed to settle for about $3 \mathrm{~h}$ without shaking. The $\mathrm{pH}$ was maintained at 7.0 \pm 0.5 using a $\mathrm{pH}$ controller and $10 \% \mathrm{CO}_{2}$-air mixture. The DCW and $\mathrm{N}, \mathrm{P}$ concentration were measured every two days over a period of 12 days and then based on these data, the removal rate was calculated. The total dissolved $\mathrm{N}$ and $\mathrm{P}$ concentrations were measured using a Nitrogen Cell Test kit (HC682368; Merck, Darmstadt, Germany) and Phosphate Cell Test kit (HC570746; Merck), respectively, according to the manufacturers' instructions. The $\mathrm{N}$ and $P$ removal rates per DCW were then calculated using the following equation.

$$
\mathrm{N} \text { or } \mathrm{P} \text { removal rate }\left(\mathrm{mg} \mathrm{g}^{-1} \mathrm{~d}^{-1}\right)=
$$

${\text { Nutrient } \text { concentration }_{d}-\text { Nutrient concentration }_{(\mathrm{d}+2)}}$

$$
2 \cdot \operatorname{DCW}_{(\mathrm{d}+2)}
$$

, where nutrient concentration $\mathrm{d}_{\mathrm{d}}$ and nutrient concentration $_{\mathrm{d}+2}$ are the nutrient concentration ( $\mathrm{N}$ or $\mathrm{P}$ ) at initial day (d) and after every 2 days $(\mathrm{d}+2)$ of cultivation, respectively. $\mathrm{DCW}_{\mathrm{d}+2}$ refers to the DCW $\left(\mathrm{g} \mathrm{L}^{-1}\right)$ every 2 days.

\section{Chemostat culture}

A continuous culture system was used to confirm whether the strain is suited for sustainable biomass production and water quality improvement. Thus, a chemo- 
stat system was used for the continuous cultivation of Ettlia sp. YC001 (Fig. 1). The chemostat reactors included gas and culture medium in-out ports in 1-L glass widemouth bottles. The working volume was $800 \mathrm{~mL}$ and the other conditions were the same as those in the batch culture experiments. The reservoir was set to settle down the cultured Ettlia sp. YC001 resulting in the clear residual water. Pond water with minimal additional nutrients was used as the medium for the continuous culture operation. The total $\mathrm{N}$ and $\mathrm{P}$ concentrations in the medium were adjusted to 45.0 and $2.79 \mathrm{mg} \mathrm{L}^{-1}(\mathrm{~N}: \mathrm{P}=16: 1)$, respectively. The medium was continuously supplied to the reactors using digital peristaltic pumps (EMP-600A; EMS Tech, Suwon, Korea). The chemostat cultures were conducted twice at three different dilution rates (1st experiment dilution rates: $0.1,0.2$, and $0.34 \mathrm{~d}^{-1}$; 2 nd experiment dilution rates: 0.3, 0.6, and $0.9 \mathrm{~d}^{-1}$ ). The Ettlia sp. YC001 culture was adequately mixed by stirring at $200 \mathrm{rpm}$, and the cell biomass was investigated every day using DCW measurements. When the cell biomass showed no increasing or decreasing trend for three consecutive days and no further change of more than $5 \%$, the chemostat was determined to be in a steady-state.

\section{Turbidity measurement}

The turbid water was collected from a landscape pond at KAIST, Korea, as previously mentioned. The pond water was filtered through a mesh $(\varnothing, 100 \mu \mathrm{m})$ to remove any large particles, such as leaves, animal feces, and protists. The turbidity was measured using a turbidity meter (TU-2016; Lutron Electronic Enterprise, Taipei, Taiwan). For the batch cultures, stirring was conducted for $30 \mathrm{~min}$ at $200 \mathrm{rpm}$. The sampling for the turbidity measurements was then carried out after $3 \mathrm{~h}$ of standing. The initial turbidity of the pond water was 22.69 NTU. For the chemostat cultures, the turbidity was measured in the reservoir containing effluent from the PBR, as the chemostat reactors needed to be kept homogeneous.

\section{Turbidity reduction at different $\mathrm{pHs}$}

The turbidity reduction was investigated under different $\mathrm{pH}$ conditions. Initially, at a neutral $\mathrm{pH}$ (7.5), cells from the pre-culture were harvested using a centrifuge (3,500 rpm, 15 min, combi514R; Hanil, Incheon, Korea). The harvested cells were then suspended in $5 \mathrm{~mL}$ of the turbid pond water. The cell-mixed pond water cultures were then adjusted to five different pHs (8.5, 9.5, 10.5, 11.5 , and 12.3) by adding drops of a $100 \mathrm{mM} \mathrm{NaOH}$ so-

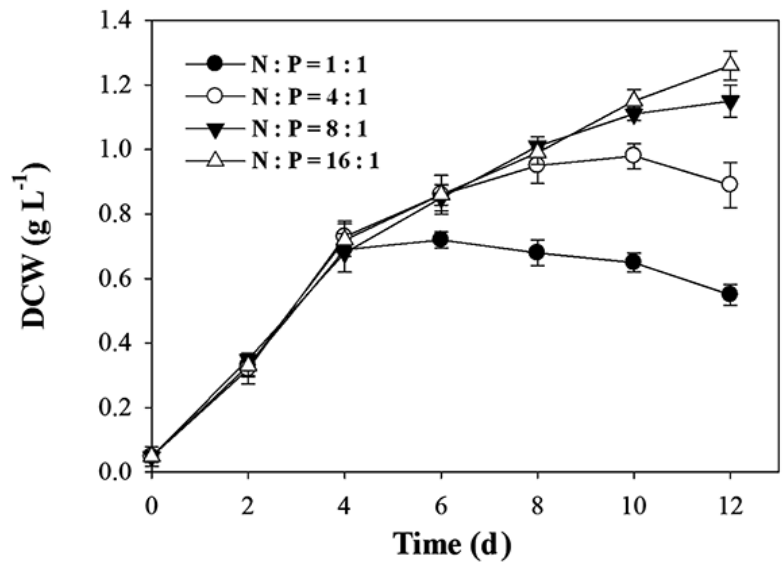

Fig. 2. Growth curves for Ettlia sp. YC001 with different weight N : $P$ ratios. The final $P$ concentration was fixed at $9.1 \mathrm{mg} \mathrm{L}^{-1}$, while four different $\mathrm{N}$ concentrations $\left(10.4,39.6,79.0\right.$, and $\left.151 \mathrm{mg} \mathrm{L}^{-1}\right)$ were set for different $\mathrm{N}$ : $\mathrm{P}$ ratios. DCW, dry cell weight. Each value indicates mean \pm standard deviation for duplicate samples.

lution. After the $\mathrm{pH}$ adjustment, the turbidity was measured immediately and then re-measured after $3 \mathrm{~h}$. The turbidity removal efficiency was calculated using the following equation.

Turbidity reduction efficiency $(\%)=(1-\mathrm{A} / \mathrm{B}) \times 100 \%$

A: Final turbidity (NTU) of culture after $3 \mathrm{~h}$ of standing $(3 \mathrm{~h})$

B: Initial turbidity (NTU) immediately after $\mathrm{pH}$ adjustment $(0 \mathrm{~h})$

\section{RESULTS AND DISCUSSION}

\section{Optimization of $\mathrm{N}$ : P ratio for Ettlia sp. YC001 cultivation in batch culture}

The batch culture growth of the Ettlia sp. YC001 was monitored with four different weight $\mathrm{N}$ : $\mathrm{P}$ ratios (Fig. 2). As the $\mathrm{N}$ : P ratio increased, the growth also increased. The maximum biomass of $1.26 \mathrm{~g} \mathrm{~L}^{-1}$ was observed with 16 : $1(\mathrm{~N}: \mathrm{P})$ after 12 days. While not the best growth recorded for Ettlia, it still shows potential for biomass production using pond water. The concentrations of dissolved $\mathrm{N}$ and $\mathrm{P}$ were measured in the culture medium, plus the nutrient removal rates according to the DCW were calculated with different $\mathrm{N}$ : P ratios (Fig. 3). While the $\mathrm{N}$ removal rates according to the DCW differed significantly depending on the $\mathrm{N}$ : P ratio, the $\mathrm{P}$ removal rates did not. In general, microalgae require a higher quantity of $\mathrm{N}$ than $\mathrm{P}$. Therefore, the $\mathrm{N}$ removal rate increased faster than the $\mathrm{P}$ removal rate with an increasing DCW. Therefore, the growth was 

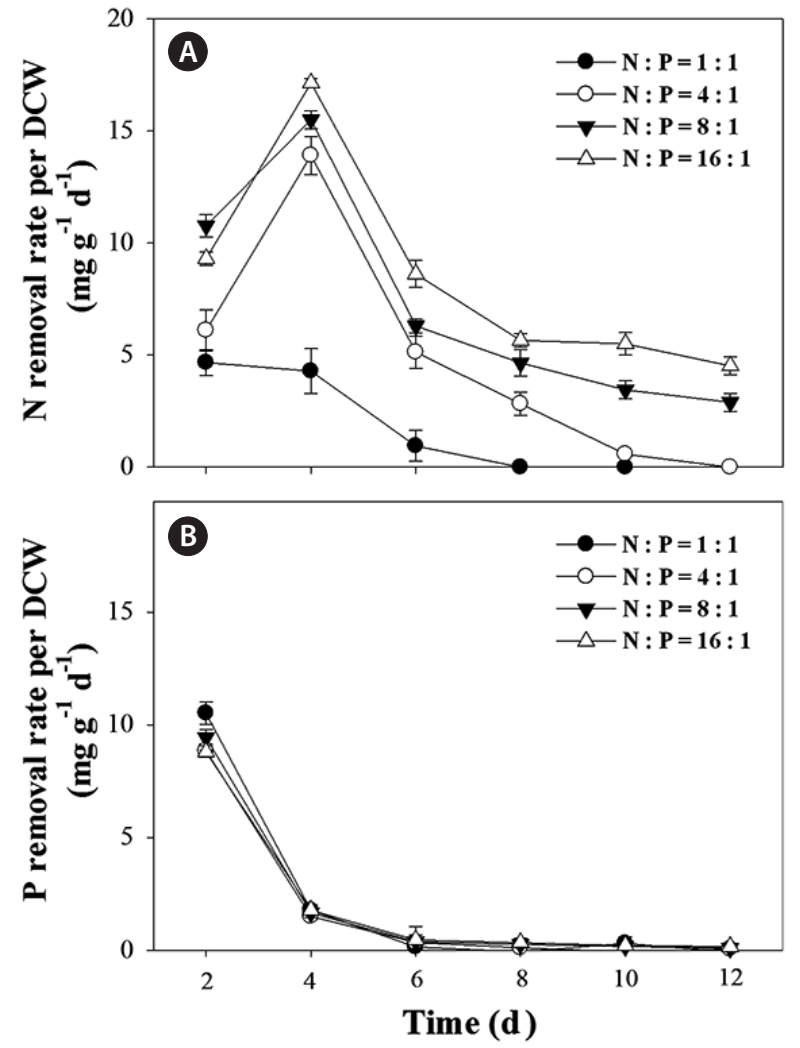

Fig. 3. Nitrogen (A) and phosphorus (B) removal rates according to dry cell weight $(D C W)$ with different weight $N$ : $P$ ratios. Each value indicates mean \pm standard deviation for duplicate samples.

seemingly more dependent on the $\mathrm{N}$ concentration than the $\mathrm{P}$ concentration, where the highest $\mathrm{N}$ removal rate occurred on days 2-4 with the maximum biomass under 16 : 1 conditions. Therefore, this result indicates that when using pond water or wastewater to supply nutrients, additional $\mathrm{N}$ or $\mathrm{P}$ may be required to reach the optimum $\mathrm{N}$ : P ratio for microalgal growth (Klausmeier et al. 2004), resulting in the complete removal of both $\mathrm{N}$ and P. Previously, many studies have reported the role of $\mathrm{P}$ in algal biomass production and nutrient uptake (Cembella et al. 1982, Wu et al. 2012, Singh et al. 2018). Wu et al. (2012) suggested that continuous supply of $\mathrm{P}$ had no significant effect on the biomass productivity of Scenedesmus sp. LX1 and excess uptake of $\mathrm{P}$ without growth, may generate $\mathrm{P}$-waste during algal biomass production. While, $\mathrm{P}$ starvation led to decreased P content and a considerable increase in biomass yield. In this study, rather than emphasizing the absorption of $\mathrm{P}$ only, influence of $\mathrm{N}$ : P ratio on algae growth was investigated with an objective of improving the water quality by minimizing the residual $\mathrm{N}$ and $\mathrm{P}$ of the culture after algal cultivation.
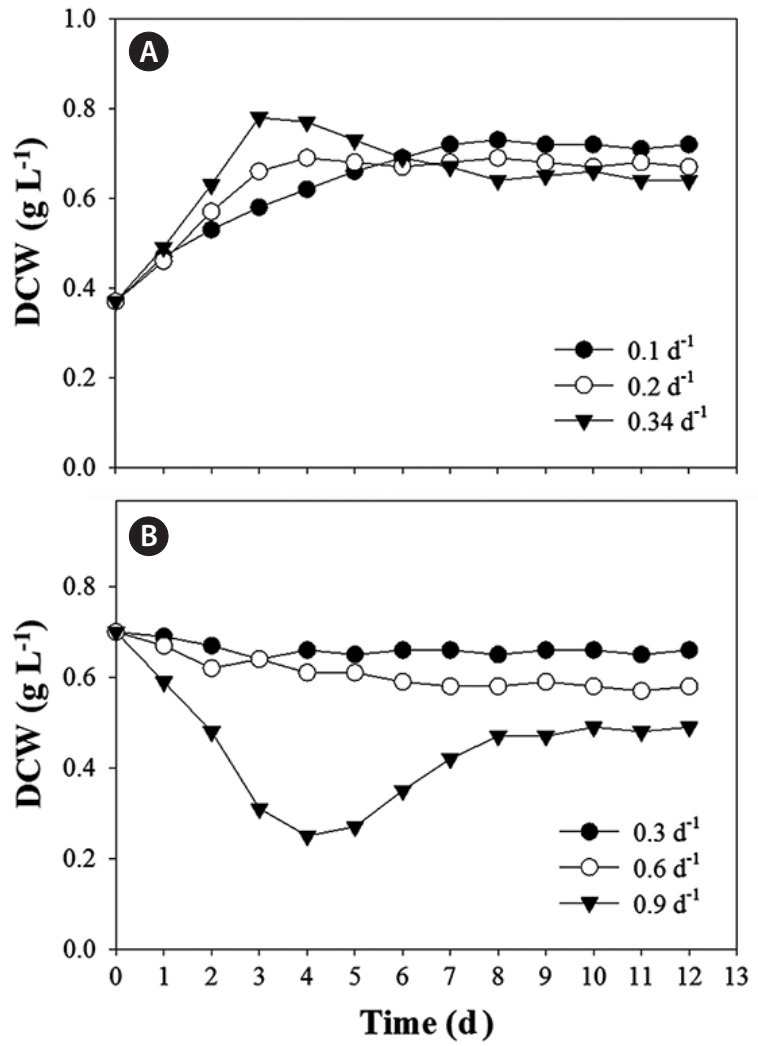

Fig. 4. Growth curves with different dilution rates in chemostat: $1 \mathrm{st}$ chemostat culture (A) and 2nd chemostat culture (B). The total $\mathrm{N}$ and $P$ concentrations in the medium were adjusted to 45.0 and $2.79 \mathrm{mg}$ $L^{-1}(N: P=16: 1)$, respectively. DCW, dry cell weight.

\section{Biomass and lipid production in chemostat cul- ture using pond water}

A steady-state was reached on day 9 of cultivation at all the dilution rates (Fig. 4). When measuring the nutrient concentrations throughout the cultivation period, $\mathrm{N}$ was confirmed as a limiting factor in the chemostat (Fig. 5). On day 7 of cultivation at three dilution rates, the total dissolved $\mathrm{N}$ decreased below the detection limit, while the total dissolved $\mathrm{P}$ decreased to a range of $0.13-0.16 \mathrm{mg}$ $\mathrm{L}^{-1}$. At a dilution rate of $1.02 \mathrm{~d}^{-1}$, cells were washed out, so the dilution rate decreased to $0.9 \mathrm{~d}^{-1}$. The steady-state nutrient removal rate, biomass productivity and lipid productivity were all compared among the five dilution rates (Table 1). The dilution rate of $0.9 \mathrm{~d}^{-1}$ produced the highest $\mathrm{N}$ and $\mathrm{P}$ removal rate at 32.4 and $1.83 \mathrm{mg} \mathrm{L}^{-1} \mathrm{~d}^{-1}$, respectively. The same dilution rate of $0.9 \mathrm{~d}^{-1}$ also produced the highest biomass productivity and lipid productivity at $0.432 \mathrm{~g} \mathrm{~L}^{-1} \mathrm{~d}^{-1}$ and $67.8 \mathrm{mg} \mathrm{L}^{-1} \mathrm{~d}^{-1}$, respectively. Following the general patterns of chemostat cultivation (Oh et al. $2000,2017)$, the nutrient removal rate and biomass pro- 


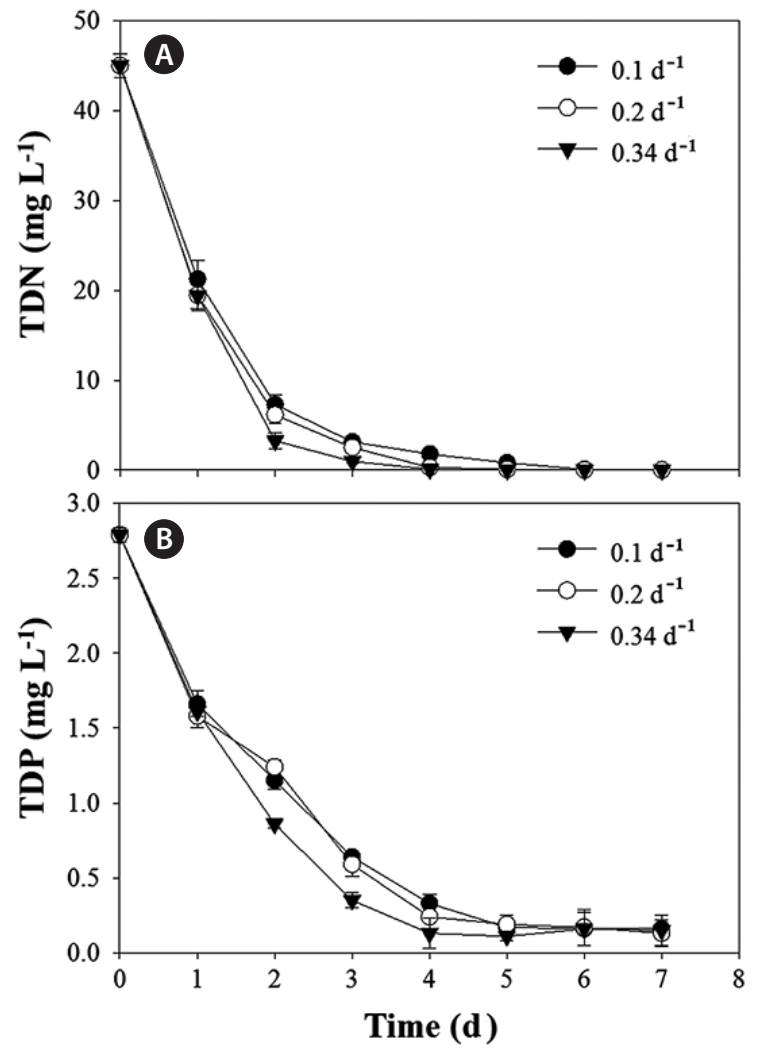

Fig. 5. Total dissolved nitrogen (TDN) (A) and phosphorus (TDP) (B) with different dilution rates in chemostat. Each value indicates mean \pm standard deviation for duplicate samples.

ductivity both increased with a higher dilution rate. However, the cell lipid content was only $15.7 \%$ at a dilution rate of $0.9 \mathrm{~d}^{-1}$, while it was $21.6 \%$ at $0.3 \mathrm{~d}^{-1}$. Notwithstanding, even though a dilution rate of $0.9 \mathrm{~d}^{-1}$ showed the lowest lipid content, it still yielded the highest lipid productivity as it generated the highest biomass productivity.

\section{Clarification of pond water by reducing turbidity}

The flocculating and rapid-settling characteristics of Ettlia sp. YC001 are useful for clearing turbid water. For

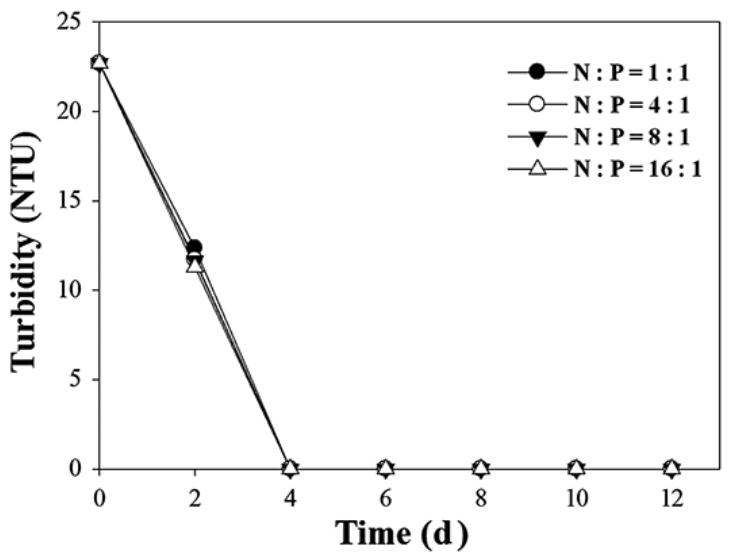

Fig. 6. Turbidity reduction in batch cultures with different weight $\mathrm{N}: \mathrm{P}$ ratios. NTU, nephelometric turbidity unit. Each value indicates mean \pm standard deviation for duplicate samples.

the landscape pond water from KAIST, the turbidity decreased from 22.69 to 0 NTU after 4 days in the case of the Ettlia sp. YC001 batch cultures, regardless of the weight N : P ratio (Fig. 6). A turbidity reduction between the influent and effluent was also obvious in the chemostat cultures (Supplementary Fig. S1). Moreover, the algal biomass and treated clear water were easily separated in the effluent reservoir, indicating that the cultivation of Ettlia sp. YC001 could be advantageous for both biomass harvest and water treatment. When the turbidity reduction was compared at different $\mathrm{pHs}$, the turbidity reduction efficiency increased with increasing pH (Fig. 7, Supplementary Fig. S2). The turbidity reduction was almost absolute at $\mathrm{pH} 11.5$ to 12.3 , with immediate floc formation within less than $5 \mathrm{~min}$, while $\mathrm{pH} 9.5$ to 10.5 reduced the turbidity by $50 \%$. The results of reduction in turbidity with increasing $\mathrm{pH}$ and floc formation were in accordance with previous study by Yoo et al. (2015). The authors showed that at pH 6.5-9.5, the Ettlia sp. YC001 cells were mostly all single in the culture medium, whereas large-sized microalgal flocs of over $120 \mu \mathrm{m}$ in diameter were predominant above $\mathrm{pH}$ 10.5. Solubility of multivalent metal ions, zeta

Table 1. Nitrogen and phosphorus removal rate and lipid production at steady-state with different dilution rates

\begin{tabular}{|c|c|c|c|c|c|c|}
\hline \multirow[b]{2}{*}{$\begin{array}{l}\text { Dilution rate } \\
\qquad\left(\mathrm{d}^{-1}\right)\end{array}$} & \multicolumn{2}{|c|}{ Water treatment } & \multicolumn{4}{|c|}{ Biomass and lipid production } \\
\hline & $\begin{array}{l}\text { N removal rate } \\
\left(\mathrm{mg} \mathrm{L}^{-1} \mathbf{d}^{-1}\right)\end{array}$ & $\begin{array}{l}\text { P removal rate } \\
\left(\mathrm{mg} \mathrm{L}^{-1} \mathrm{~d}^{-1}\right)\end{array}$ & $\begin{array}{l}\text { Steady-state } \\
\text { cell density } \\
\left(\mathrm{g} \mathrm{L}^{-1}\right)\end{array}$ & $\begin{array}{l}\text { Biomass } \\
\text { productivity } \\
\left(\mathrm{g} \mathrm{L}^{-1} \mathrm{~d}^{-1}\right)\end{array}$ & $\begin{array}{l}\text { Lipid content } \\
(\%, w / w)\end{array}$ & $\begin{array}{l}\text { Lipid productivity } \\
\left(\mathrm{mg} \mathrm{L}^{-1} \mathrm{~d}^{-1}\right)\end{array}$ \\
\hline 0.1 & 4.32 & 0.267 & 0.718 & 0.068 & - & - \\
\hline 0.2 & 8.99 & 0.558 & 0.673 & 0.136 & - & - \\
\hline 0.3 & 10.80 & 0.499 & 0.655 & 0.195 & 21.6 & 42.1 \\
\hline 0.6 & 21.60 & 1.190 & 0.578 & 0.342 & 18.6 & 63.6 \\
\hline 0.9 & 32.40 & 1.830 & 0.488 & 0.432 & 15.7 & 67.8 \\
\hline
\end{tabular}




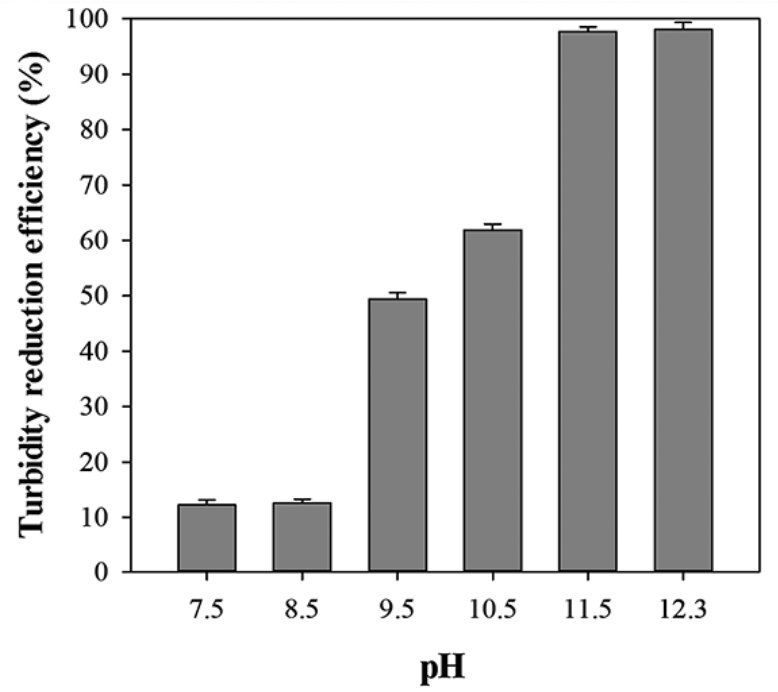

Fig. 7. Turbidity reduction efficiency at different $\mathrm{pHs}$. Each value indicates mean \pm standard deviation for duplicate samples.

potential of particles, and chemical characteristics of extracellular polymeric substances (EPS) are shown to be affected by the culture medium $\mathrm{pH}$ (Yoo et al. 2015), that in turn can influence the flocculating activity of the microalgae. Large flocs for Ettlia texensis has been shown to be related to EPS on the cell surface rather than neutralization of the zeta potential (Salim et al. 2014). Therefore, auto-flocculation apparently played an important role in the turbidity reduction.

\section{Application of pond water purification to algae cultivation}

Pond water purification using microalgae is an environmentally friendly and sustainable algal control technique. Yet, while water treatment processes using microorganisms are excellent for removing organic matter, they are ineffective in removing such nutrients as $\mathrm{N}$ and $\mathrm{P}$ (De-Bashan et al. 2004). Microalgae can be converted into valuable resources via the use of $\mathrm{N}$ and $\mathrm{P}$, which otherwise cause eutrophication of water systems. In the present study, nutrient removal was achieved to a low concentration range of $0.13-0.16 \mathrm{mg} \mathrm{L}^{-1} \mathrm{P}$ which is slightly lower than effluent guideline in the group 1 region to protect drinking water resources $\left(\mathrm{P}<0.2 \mathrm{mg} \mathrm{L}^{-1}\right.$, http://www. me.go.kr). However, for perfect nutrient removal, artificial adjustment of the optimal $\mathrm{N}$ : $\mathrm{P}$ ratio was required in accordance with the $\mathrm{N}$ and $\mathrm{P}$ absorption rate of the microalgae. Thus, further studies are needed for flexible control of the inflow nutrient concentration.
Recycling the biomass of microalgae is relatively easy when compared to the biomass of other microorganisms as microalgae tend to accumulate useful components (Arnold 2013, Pignolet et al. 2013, Randrianarison and Ashraf 2017). Thus, instead of discarding the bacterial biomass from conventional wastewater treatment as waste sludge, the use of microalgae can solve this additional pollution problem. Thus, various technologies are being investigated to utilize microalgae for water purification and then use the algal biomass for green technologies.

Eventually, the application scale can be expanded beyond landscape ponds to agricultural reservoirs and livestock wastewater treatment plants for water quality improvement. Furthermore, a higher biomass productivity and nutrient removal rate can be secured by utilizing the exhaust gas from nearby facilities or residual heat from heating systems. Therefore, diversifying the fields of application will surely increase the potential of the microalgae water treatment industry.

\section{CONCLUSION}

In this study, the Ettlia sp. YC001 showed the highest $\mathrm{N}$ removal and growth with a weight $\mathrm{N}: \mathrm{P}$ ratio of 16 : 1. Moreover, at $16: 1 \mathrm{~N}: \mathrm{P}$ ratio, all $\mathrm{N}$ and $\mathrm{P}$ were completely removed from the pond water. In the chemostat culture, the biomass productivity and nutrient removal rate increased with an increasing dilution rate. Therefore, the highest water treatment efficiency and biomass production were both achieved at the highest dilution rate of $0.9 \mathrm{~d}^{-1}$. While the turbidity reduction was not dependent on the $\mathrm{N}$ : P ratio, it was significantly influenced by the auto-flocculation activity of Ettlia sp. YC001 at different pHs. Thus, water purification using microalgae such as Ettlia sp. YC001 may be an effective option for the ecofriendly recovery and bioremediation of eutrophic ponds and reservoirs, while also generating useful biomass byproducts.

\section{ACKNOWLEDGEMENTS}

This research was supported by the Advanced Biomass R\&D Center, a Global Frontier Program, funded by the Korean Ministry of Science and ICT (2010-0029723). We are also grateful to anonymous reviewers for their detailed and valuable comments on this study. 


\section{SUPPLEMENTARY MATERIAL}

Supplementary Fig. S1. The overall experimental equipment of chemostat cultivation (A), the influent turbid pond water (turbidity 87 nephelometric turbidity unit [NTU]) (B), and the effluent after chemostat culture for 3 days (turbidity 1.37 NTU) (C) (http://www.e-algae. org).

Supplementary Fig. S2. Ettlia sp. YC001 flocs after 5 min of pH adjustment (A) and sedimentation of Ettlia sp. YC001 flocs after $3 \mathrm{~h}$ of pH adjustment (B) (http:/ / www.ealgae.org).

\section{REFERENCES}

Acién, F. G., Gómez-Serrano, C., Morales-Amaral, M. M., Fernández-Sevilla, J. M. \& Molina-Grima, E. 2016. Wastewater treatment using microalgae: how realistic a contribution might it be to significant urban wastewater treatment? Appl. Microbiol. Biotechnol. 100:9013-9022.

Arnold, M. 2013. Sustainable algal biomass products by cultivation in waste water flows. VTT Technol. 147:1-84.

Bligh, E. G. \& Dyer, W. J. 1959. A rapid method of total lipid extraction and purification. Can. J. Biochem. Physiol. 37:911-917.

Cembella, A. D., Antia, N. J. \& Harrison, P. J. 1982. The utilization of inorganic and organic phosphorous compounds as nutrients by eukaryotic microalgae: a multidisciplinary perspective: part I. CRC Crit. Rev. Microbiol. 10:317-391.

Chun, S. -J., Cui, Y., Ahn, C. -Y. \& Oh, H. -M. 2018. Improving water quality using settleable microalga Ettlia sp. and bacterial community in freshwater recirculating aquaculture system of Danio rerio. Water Res. 135:112-121.

De-Bashan, L. E., Hernandez, J. -P., Morey, T. \& Bashan, Y. 2004. Microalgae growth-promoting bacteria as "helpers" for microalgae: a novel approach for removing ammonium and phosphorus from municipal wastewater. Water Res. 38:466-474.

Hammed, A. M., Prajapati, S. K., Simsek, S. \& Simsek, H. 2016. Growth regime and environmental remediation of microalgae. Algae 31:189-204.

Heisler, J., Glibert, P. M., Burkholder, J. M., Anderson, D. M., Cochlan, W., Dennison, W., Dortch, Q., Gobler, C. J., Heil, C. A., Humphries, E., Lewitus, A., Magnien, R., Marshall, H. G., Sellner, K., Stockwell, D. A., Stoecker, D. K. \& Suddleson, M. 2008. Eutrophication and harmful algal blooms: a scientific consensus. Harmful Algae 8:3-13.

Kim, C. -J., Jung, Y. -H., Ahn, C. -Y., Lee, Y. -K. \& Oh, H. -M.
2010. Adsorption of turbid materials by the cyanobacterium Phormidium parchydematicum. J. Appl. Phycol. 22:181-186.

Klausmeier, C. A., Litchman, E., Daufresne, T. \& Levin, S. A. 2004. Optimal nitrogen-to-phosphorus stoichiometry of phytoplankton. Nature 429:171-174.

La, H. -J., Seo, S. -H., Lee, J. -Y., Lee, C. S., Kim, B. -H., Srivastava, A., Han, M. -S. \& Oh, H. -M. 2016. Improved mixing efficiency and biomass productivity of Ettlia sp. in cocultivation system with loaches. Algal Res. 17:300-307.

Lee, N., Ko, S. -R., Ahn, C. -Y. \& Oh, H. -M. 2018. Optimized co-production of lipids and carotenoids from Ettlia sp. by regulating stress conditions. Bioresour. Technol. 258:234-239.

Oh, H. -M., Lee, S. J., Jang, M. -H. \& Yoon, B. -D. 2000. Microcystin production by Microcystis aeruginosa in a phosphorus-limited chemostat. Appl. Environ. Microbiol. 66:176-179.

Oh, H. -S., Lee, C. S., Srivastava, A., Oh, H. -M. \& Ahn, C. -Y. 2017. Effects of environmental factors on cyanobacterial production of odorous compounds: geosmin and 2-methylisoborneol. J. Microbiol. Biotechnol. 27:13161323.

Park, M. K., Lee, S. J., Suh, H. -H., Kim, H. -S., Kim, Y. H., Yoon, B. -D. \& Oh, H. -M. 1998. Advanced treatment of swine wastewater by a green alga, Scenedesmus quadricauda. Algae 13:227-233.

Pignolet, O., Jubeau, S., Vaca-Garcia, C. \& Michaud, P. 2013. Highly valuable microalgae: biochemical and topological aspects. J. Ind. Microbiol. Biotechnol. 40:781-796.

Randrianarison, G. \& Ashraf, M. A. 2017. Microalgae: a potential plant for energy production. Geology, Ecology, and Landscapes 1:104-120.

Rezvani, F, Sarrafzadeh, M. -H., Seo, S. -H. \& Oh, H. -M. 2017. Phosphorus optimization for simultaneous nitrate-contaminated groundwater treatment and algae biomass production using Ettlia sp. Bioresour. Technol. 244:785792.

Rhee, G.-Y. 1978. Effects of N:P atomic ratios and nitrate limitation on algal growth, cell composition, and nitrate uptake. Limnol. Oceanogr. 23:10-25.

Rhee, G.-Y. \& Gotham, I. J. 1980. Optimum N:P ratios and coexistence of planktonic algae. J. Phycol. 16:486-489.

Salim, S., Kosterink, N. R., Tchetkoua Wacka, N. D., Vermue, M. H. \& Wijffels, R. H. 2014. Mechanism behind autoflocculation of unicellular green micro algae Ettlia texensis. J. Biotechnol. 174:34-38.

Scott, S. A., Davey, M. P., Dennis, J. S., Horst, I., Howe, C. J., Lea-Smith, D. J. \& Smith, A. G. 2010. Biodiesel from algae: challenges and prospects. Curr. Opin. Biotechnol. 
21:277-286

Singh, D., Nedbal, L. \& Ebenhöh, O. 2018. Modelling phosphorus uptake in microalgae. Biochem. Soc. Trans. 46:483-490.

Solovchenko, A., Verschoor, A. M., Jablonowski, N. D. \& Nedbal, L. 2016. Phosphorus from wastewater to crops: an alternative path involving microalgae. Biotechnol. Adv. 34:550-564.

Stanier, R. Y., Kunisawa, R., Mandel, M. \& Cohen-Bazire, G. 1971. Purification and properties of unicellular blue-green algae (order Chroococcales). Bacteriol. Rev. 35:171-205.

Whitton, R., Le Mével, A., Pidou, M., Ometto, F., Villa, R. \& Jefferson, B. 2016. Influence of microalgal N and P composition on wastewater nutrient remediation. Water Res. 91:371-378.

Woertz, I., Fulton, L. \& Lundquist, T. 2009. Nutrient removal \& greenhouse gas abatement with $\mathrm{CO}_{2}$ supplemented algal high rate ponds. In Annual Conference of Water Environment Federation, Water Environment Federation, Alexandria, VA, p. 13.

Wu, Y. -H., Yu, Y., Li, X., Hu, H. -Y. \& Su, Z. -F. 2012. Biomass production of a Scenedesmus sp. under phosphorousstarvation cultivation condition. Bioresour. Technol. 112:193-198.

Yoo, C., Choi, G. -G., Kim, S. -C. \& Oh, H. -M. 2013. Ettlia sp. YC001 showing high growth rate and lipid content under high $\mathrm{CO}_{2}$. Bioresour. Technol. 127:482-488.

Yoo, C., La, H. -J., Kim, S. -C. \& Oh, H. -M. 2015. Simple processes for optimized growth and harvest of Ettlia sp. by $\mathrm{pH}$ control using $\mathrm{CO}_{2}$ and light irradiation. Biotechnol. Bioeng. 112:288-296.

Zhang, G. \& Wang, Z. 2000. Mechanism study of the coagulant impact on mutagenic activity in water. Water Res. 34:1781-1790. 